https://doi.org/10.17816/MAJ191S126-27

\title{
PARTICIPATION OF INOS IN THE EFFECT OF IL-1 $\beta$ ON LUNG VENTILATION AND HYPOXIC CHEMORECEPTION
}

\author{
A.A. Klinnikova, G.A. Danilova, N.P. Alexandrova \\ Laboratory of Respiratory Physiology, Pavlov Institute of Physiology of RAS, Saint Petersburg, Russia

\section{РОЛЬ ИНДУЦИБЕЛЬНОЙ NO-СИНТАЗЫ В РЕАЛИЗАЦИИ РЕСПИРАТОРНЫХ ЭФФЕКТОВ ИНТЕРЛЕЙКИНА 1-БЕТА}

\author{
А.А. Клинникова, Г.А. Данилова, Н.П. Александрова \\ ФГБУН «Институт физиологии им. И.П. Павлова» РАН, Санкт-Петербург
}

With systemic inflammation, hypoxia, and an increase in the respiratory, a significant increase in the systemic level of pro-inflammatory cytokines is observed. Recently we demonstrated that elevated IL-1 $\beta$ level in blood reduces the ventilatory response to hypoxia. The aim of the present study was to examine the hypothesis that the respiratory effect of IL-1 $\beta$ may be mediating the NO-dependent mechanisms.

The experiments were performed on anaesthetized rats. We studied the effects of intravenous administration of cytokine during inhibition of iNO-synthase. In order to we used aminoguanidine bicarbonate - specific inhibitor of iNOS, which was injected in the tail vein for 30 minutes before the administration of cytokine. During the hypoxic rebreathing experiments, was found that the increase of IL-1 $\beta$ level in blood weakens the respiratory response to hypoxia. The ventilatory, tidal volume and mean inspiratory flow responses decreased by $29 \%, 31 \%$ and $53 \%$ respectively. INO-synthase inhibitor pretreatment eliminated these respiratory effects of IL-1 $1 \beta$. Thus the data indicate that the ability of IL-1 $\beta$ to reduce the ventilatory hypoxic response is mediated by the NO-dependent pathway.

Keywords: hypoxia; IL-1 $\beta$; nitric oxide.

При системном воспалении, гипоксии, увеличении нагрузки на дыхательную систему наблюдается значительный подъем системного уровня провоспалительных цитокинов. Ранее нами было показано, что повышенный уровень ИЛ- $1 \beta$ в крови значительно снижает чувствительность дыхательной систе-

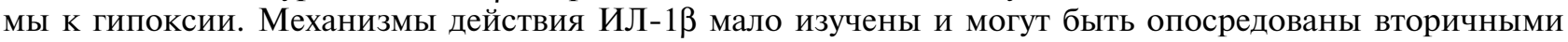
мессенджерами, в том числе оксидом азота.

Целью работы стало выяснение роли индуцибельной NO-синтазы в изменении чувствительности гипоксической хеморецепции под действием провоспалительных цитокинов.

Эксперименты проводились на наркотизированных крысах. Параметры внешнего дыхания регистрировались пневмотахографическим методом. Физиологические параметры регистрировались до внутривенной инъекции ИЛ-1 $\beta$ и каждые 20 мин. после введения на протяжении 90 мин. За 30 минут до введения цитокинов производилось внутрибрюшинное введение ингибитора iNOS аминогуанидин бикарбоната.

Установлено, что ИЛ-1ß вызывает снижение прироста вентиляторных параметров в ответ на гипоксическое воздействие. На 40 минуте действия цитокина наблюдалось снижение прироста минутного объема дыхания на $29 \%$, дыхательного объема на $31 \%$ и средней скорости инспираторного потока на $53 \%$. При введении ИЛ-1ß на фоне ингибирования iNOS, прирост параметров дыхания не снижался. Таким образом, в ослабление вентиляторного гипоксического ответа при увеличении уровня IL-1 $\beta$ могут быть вовлечены NO-зависимые механизмы.

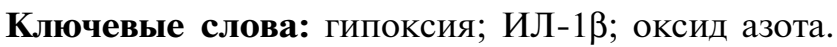

Introduction. It is known that the systemic level of the major pro-inflammatory cytokine interleukin-1 $\beta$ (IL-1 $\beta$ ) increases in many respiratory diseases such as asthma, chronic obstructive pulmonary disease, and sleep apnea (Vgontzas et al., 2011). In previous studies have shown that IL-1 $\beta$ suppresses the ventilatory hypoxic response (Aleksandrova et al., 2017). However, the mechanisms by which IL-1 $\beta$ impairs respiratory chemoreflex are still not clear, and may to involve multiple inflammatory molecules. One of these molecules may be nitric oxide. The interaction of IL- $1 \beta$ with its receptors produce the expression of inducible NO synthase, which leads to increased synthesis of NO. We hypothesized that the respiratory effects of pro-inflammatory cytokines is mediated by inducible nitric oxide synthase (iNOS).

The aim of the present study was to examine the hypothesis that the ability of IL-1 $\beta$ to reduce the hypoxic ventilatory response may be mediated by NO-dependent ways.

Material and methods. The experiments were performed in 16 tracheostomized rats (mean weight $270 \pm 10 \mathrm{~g}$ ) anaesthetized intraperitoneally with urethane $(1400 \mathrm{mg} / \mathrm{kg})$. We studied the effects of intravenous administration of cytokine during inhibition of iNO-synthase. In order to we used aminoguanidine bicarbonate - specific inhibitor of 
iNOS, that was injected in the tail vein at $50 \mathrm{mg} / \mathrm{kg}$ for 30 minutes before the administration of cytokine. IL-1 $\beta$ was administrated in the tail vein in an amount of $500 \mathrm{ng} / \mathrm{rat}$. The ventilatory hypoxic response was measured by using rebreathing techniques before and at 20,40, 60, and 90 minute after administration of IL-1 $\beta$. The animals breathed from a bag with gas mixture $\left(15 \% \mathrm{O}_{2}, 5 \% \mathrm{CO}_{2}\right.$, and $80 \% \mathrm{~N}_{2}$ ). A gradual decrease in end tidal $\mathrm{O}_{2}$ was recorded for 4 minutes, and was monitored on a breath by-breath basis. Control measurements were performed by administration of $10 \mu \mathrm{l}$ of saline (placebo). All animal procedures were conducted in accordance with the ethical guidelines of the European Community Council Directives 86/609/EEC.

Results and discussion. During hypoxia, significant correlation was observed between minute ventilation, tidal volume, mean inspiratory flow, and decrease in $\mathrm{P}_{\mathrm{ET}} \mathrm{O}_{2}$, both before and after injections of IL-1 $\beta$. However, IL-1 $\beta$ decreased the ventilatory response to hypoxia, and flattened the hypoxic response slopes with maximal changes observed from 40 minute after injection. The slope of the hypoxic ventilatory response decreased almost twofold from $10.4 \pm 3.02$ to $4.06 \pm 0.86 \mathrm{~mL} \mathrm{~min}{ }^{-1} \mathrm{mmHg}^{-1}$
$(-61 \%) 40 \mathrm{~min}$ after administration of IL-1 $\beta$ $(p<0.05)$. The slope of tidal volume and mean inspiratory flow also decreased from $0.074 \pm 0.02$ to $0.039 \pm 0.01 \mathrm{~mL} \mathrm{mmHg}-1(-45 \%, p<0.05)$, and from $0.36 \pm 0.07$ to $0.2 \pm 0.04 \mathrm{~mL} \mathrm{~s}^{-1} \mathrm{mmHg}^{-1}$ $(-46 \%, p<0.05)$, respectively. For comparison, intravenous injection of saline did not affect response slopes. Pretreatment with inhibitor of iNOS significantly reduced respiratory effects of IL- $1 \beta$. Under the action of aminoguanidine bicarbonate IL-1 $\beta$ did not cause a flattening of the hypoxic response slopes.

Conclusion. Thus, the data demonstrate a significantly attenuation in the hypoxic ventilatory response after IL- $1 \beta$ elevated in blood of anesthetized rats. The results also show that the action of the proinflammatory cytokine on the respiratory system is determined by NO-dependent mechanisms. It is known that a large number of IL- $1 \beta$ receptors (one of the main iNOS inducers) are located in the endothelium of blood vessels. The interaction of this cytokine with receptors produce the expression of inducible NO synthase, which may be involved in the attenuation of the ventilatory response to hypoxia induced by increase in systemic level of IL-1 $\beta$.

\section{References}

1. Aleksandrova NP, Danilova GA, Aleksandrov VG. Interleukin-1beta suppresses the ventilatory hypoxic response in rats via prostaglandin-dependent pathways. Can. J. Physiol.Pharmacol. 2017;95(6):681-685.

2. Vgontzas AN, Papanicolaou DA, Bixler EO, et al. Sleep Apnea and Daytime Sleepiness and Fatigue: Relation to Visceral Obesity, Insulin Resistance, and Hypercytokinemia. J. Clin. Endocrin. \& Metab. 2000;85:11511158 . 